\title{
Originals
}

\section{Glucose transporter gene expression in rat conceptus during high glucose culture}

\author{
Y. Takao, S. Akazawa, K. Matsumoto, H. Takino, M. Akazawa, R. A. Trocino, Y. Maeda, S. Okuno, E. Kawasaki, \\ S. Uotani, A. Yokota, S. Nagataki
}

The First Department of Internal Medicine, Nagasaki University School of Medicine, Nagasaki, Japan

\begin{abstract}
Summary. We investigated the expression of glucose transporter genes and protein in embryo and yolk sac during organogenesis and the regulation of glucose transporters during culture in hyperglycaemic media. Erythrocyte-type glucose transporter (GLUT 1) and brain-type glucose transporter (GLUT 3) mRNA were expressed in embryo and yolk sac. The expression of GLUT-1 and GLUT-3 mRNA was abundant on day 9-11 and day 9-10 in the embryo, respectively, and day 9-14 and day 10-11 in the yolk sac, respectively. The levels of GLUT-1 protein in the embryo increased in parallel with the expression of GLUT-1 mRNA during the corresponding period. Immunohistochemical staining of GLUT-1 protein was found principally in the neuroepithelial cells surrounding the neural tube in the embryo on day 10 and appeared in the microvessels surrounding the neural tube after day 12 .

To test whether the expression of glucose transporter genes and protein was suppressed during hyperglycaemia,
\end{abstract}

conceptuses were cultured in high glucose medium. The abundant expression of GLUT-1 protein was not decreased during culture in high glucose media for $24 \mathrm{~h}$ (day 9-10) and was only down-regulated by prolonged exposure to this media for $48 \mathrm{~h}$ (day 9-11). We have demonstrated the predominant expression of the high affinity glucose transporter (GLUT 1 and GLUT 3) genes and (GLUT 1) protein in embryo during the early period of organogenesis. The persistently abundant expression of glucose transporter during the critical period of neural tube formation (day 9-10) even in the presence of hyperglycaemia may explain one of the mechanisms of increased glucose flux into the neuroepithelium, which may lead to neural tube defects.

Key words: Glucose transporter, embryogenesis, hyperglycaemia, rat embryo culture.
The transport of glucose into the cell is catalysed by glucose transporters, for which the cDNAs encoding five facilitative glucose transporter isoforms (the erythrocyte/ GLUT 1, liver/GLUT 2, brain/GLUT 3, muscle-fat/ GLUT 4 and small intestine/GLUT 5) have been isolated and characterized [1-9]. GLUT 1 and GLUT 3 are expressed at various levels in many human tissues and are most abundant in the brain. These two glucose transporters have a low $\mathbf{K}_{\mathrm{m}}$ for glucose. GLUT 2 is expressed in the liver and pancreatic beta cell. This isoform has a high $\mathrm{K}_{\mathrm{m}}$ and may mediate the bidirectional transfer of glucose across the plasma membrane of the liver and the glucosesensing mechanism of pancreatic beta cell. GLUT 4 is expressed in skeletal muscle, cardiac muscle and fat and is responsible for the insulin-stimulated uptake of glucose.

The postimplantation conceptus in the rat consists of embryo and extraembryonic membrane such as yolk sac, amnion and allantois. The yolk sac is initially the site for the transfer of glucose between mother and embryo before the chorioallantoic circulation is established. During the early period of organogenesis (day 9-10), the rat conceptus is totally dependent on anaerobic glycolysis which is characterized by a high rate of glucose utilization and conversion to lactic acid, with little activity of oxidative metabolism through the Krebs cycle [10,11]. These two days of the embryo correspond to the main period of neurulation. During the latter part of gestational days 11 and 12 when the tricarboxylic acid cycle begins to function, the rate of anaerobic glycolysis declines $[10,11]$. Thus, the glucose requirement dramatically changes during the development of the rat conceptus. The relationship between derangement of energy metabolism and abnormal development of the postimplantation conceptus has been reported [12-27]. When embryos were cultured in the glucose-deficient or mannose-supplemented media, malformations such as neural tube defects in association with reduction of glycolytic flux, were observed suggesting that interruption of glycolytic flux before the maturation of the Krebs cycle (day 9-10) might result in general growth retardation and neural tube defects [12-16]. 

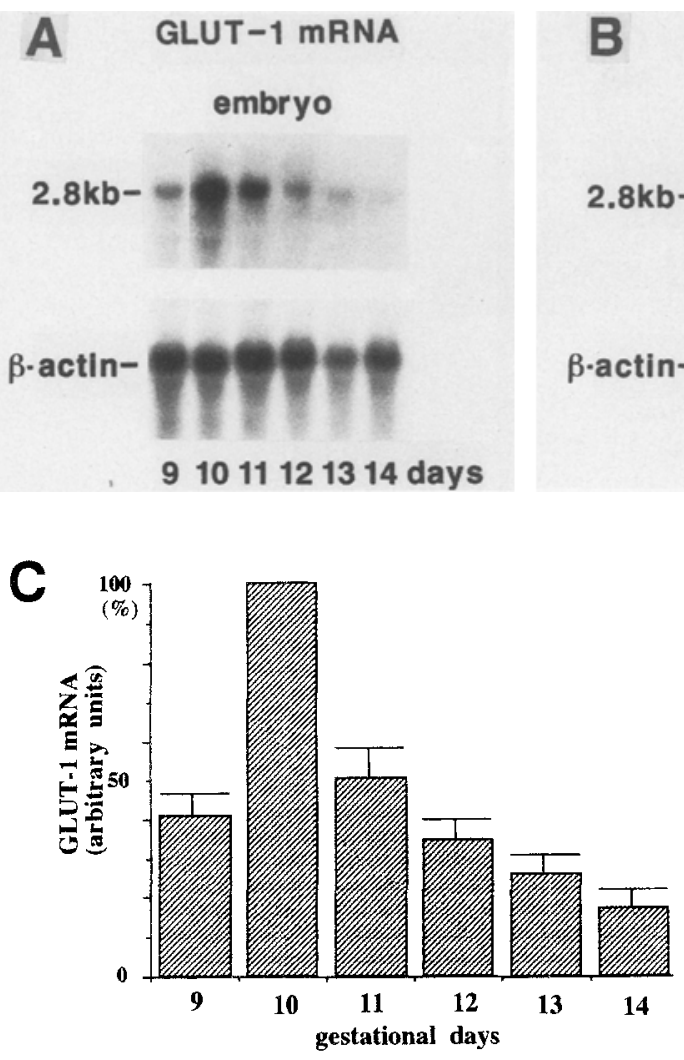

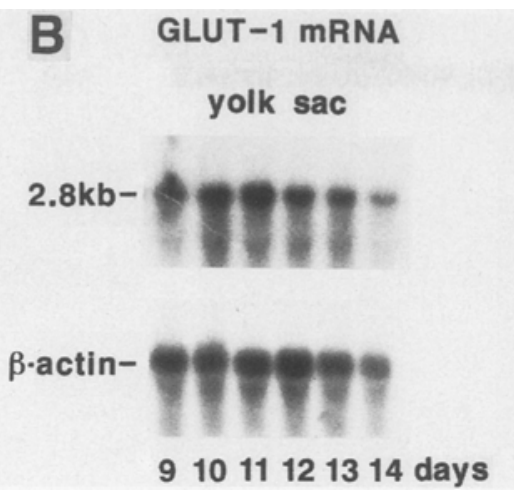

D

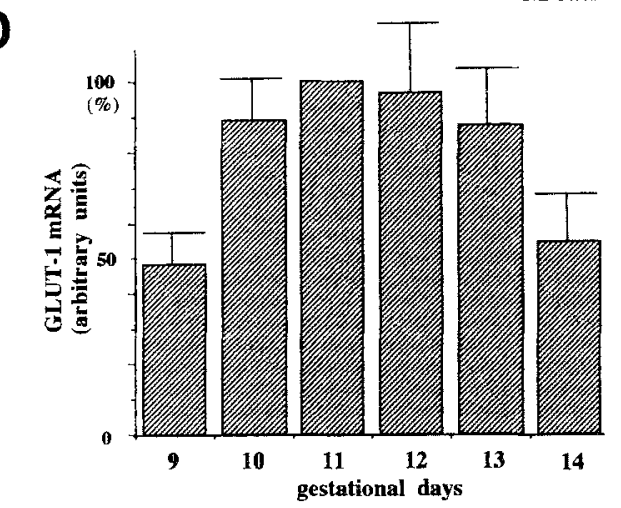

Fig. 1 A-D. Representative Northern blot (A, B) and quantitation $(\mathbf{C}, \mathbf{D})$ of GLUT-1 mRNA from the embryo and yolk sac from day 9-14 of gestation. Rat conceptuses were collected at daily intervals. Total RNA was extracted from the embryo and yolk sac on each gestational day. RNA (30 $\mu \mathrm{g}$ ) was subjected to electrophoresis, and transferred to nylon paper. The nylon filters were hybridized with the denatured cDNA probe of GLUT-1 labelled with ${ }^{32} \mathrm{P}$-dCTP and the autoradiograms were quantified using scanning densitometry. The optical density values were expressed in arbitrary units of absorbance relative to the value of the stages showing the maximal level of GLUT-1 mRNA. Each bar is the mean \pm SEM of five independent determinations
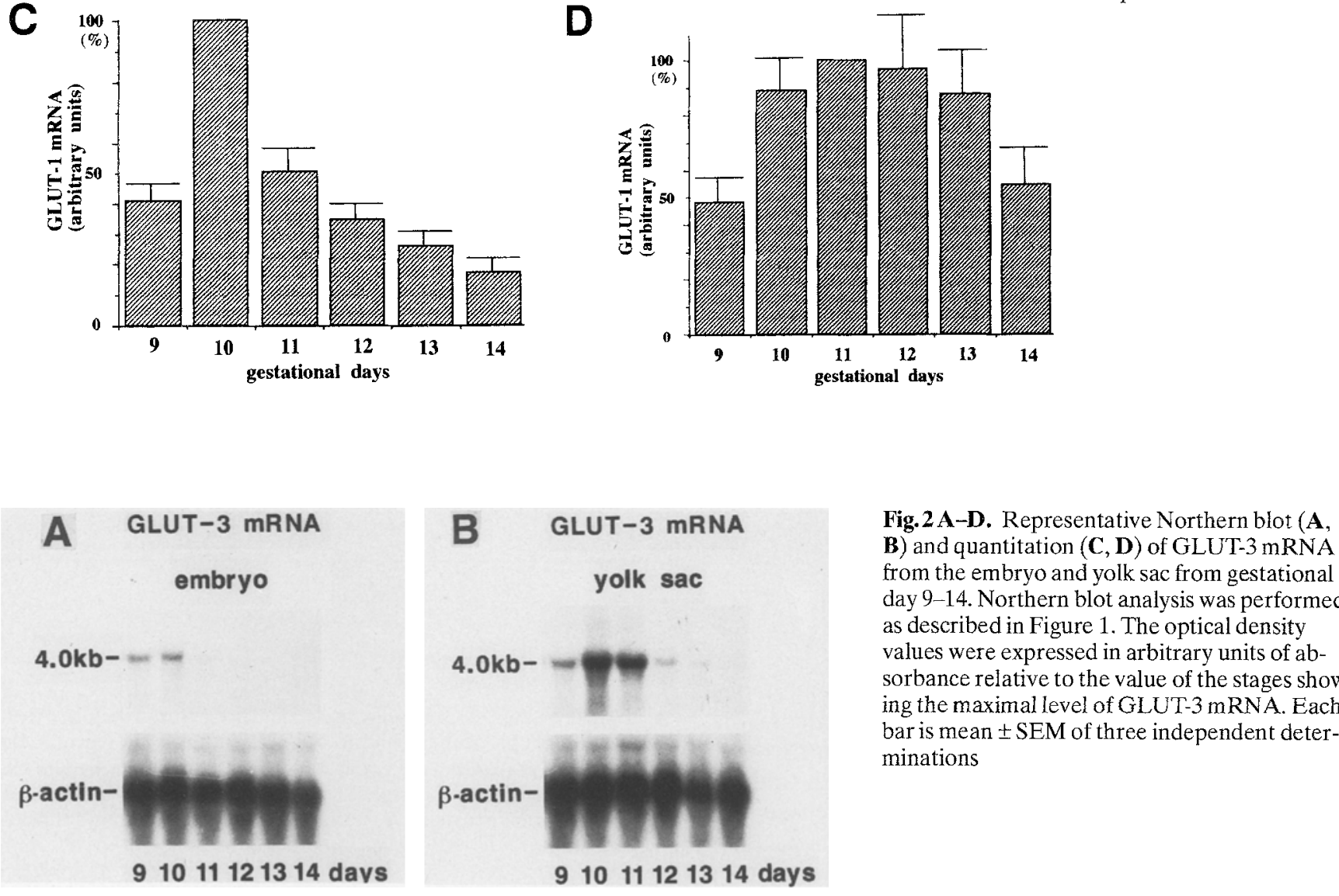

Fig. 2 A-D. Representative Northern blot (A, B) and quantitation (C, D) of GLUT-3 mRNA from the embryo and yolk sac from gestational day 9-14. Northern blot analysis was performed as described in Figure 1. The optical density values were expressed in arbitrary units of absorbance relative to the value of the stages showing the maximal level of GLUT-3 mRNA. Each bar is mean \pm SEM of three independent determinations
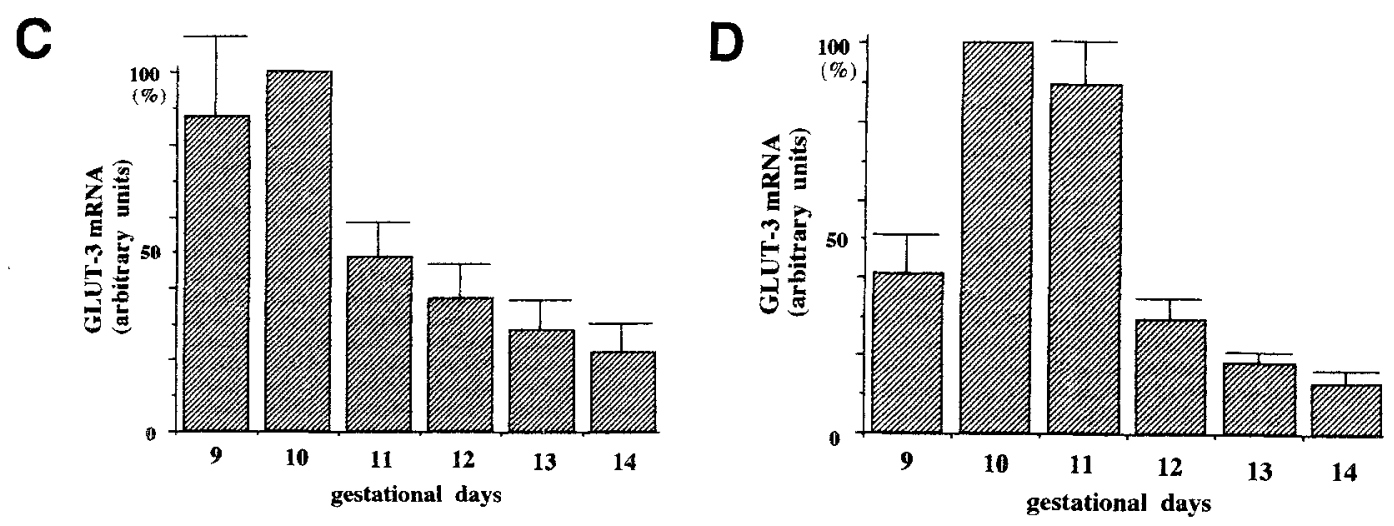

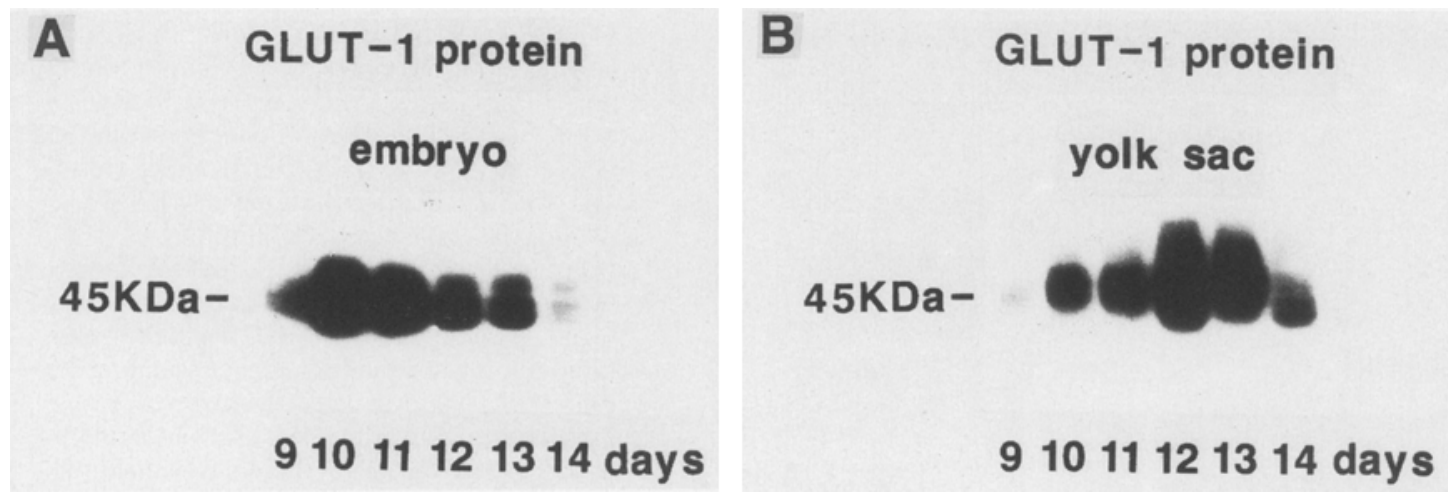

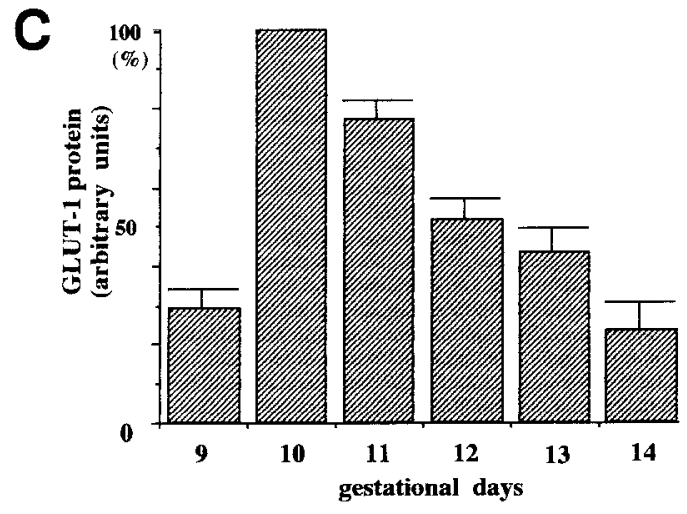

Fig.3A-D. Representative Western blot $(\mathbf{A}, \mathbf{B})$ and quantitation $(\mathbf{C}, \mathbf{D})$ of GLUT-1 protein from the embryo and yolk sac from day 9 14. Rat conceptuses were collected as described in Figure 1. Protein $(50 \mu \mathrm{g})$ in the embryo and yolk sac was resolved on SDS-PAGE, transferred to nitrocellulose paper, incubated with GLUT-1 antiserum (1:2500) followed by ${ }^{125}$ I-labelled protein $\mathrm{A}$ and subjected to

Addition of glucose to culture media (day 9-10), has been shown to cause disturbed development and malformation [17-21]. These effects might be mediated by an increased glucose flux, resulting in myo-inositol depletion or generation of free oxygen radicals in the embryos at a critical stage of organogenesis [2227].

As for the regulation of glucose transporters, an increased expression of GLUT 1 has been shown to be induced by factors that promote cell growth and division such as oncogenes, growth factors and tumour promotors $[28,29]$. It has also been reported that ambient glucose can affect both glucose transport activity and levels of the GLUT gene, and protein; increased activity of glucose transport or increased expression of GLUT, or both, may occur in the absence of glucose [30-37], while decreased activity or decreased expression, or both, are induced by the presence of high glucose [36,38-43].

We have investigated the expression of glucose transporter genes and proteins in embryo and yolk sac during the period of organogenesis. The regulation of the glucose transporter (GLUT 1, GLUT 3, GLUT 4) genes and (GLUT 1) protein was investigated in conceptuses to evaluate one of the mechanisms for excess accumulation of glucose in the embryo during high glucose exposure, which may lead to neural tube defects.

\section{Materials and methods}

Virgin female Wistar rats were mated and pregnancy was timed from the midnight preceding the morning when sperm was present in the vaginal smear. On day 9-14 of gestation, mothers were killed by cervical dislocation and conceptuses were collected at daily intervals for Northern blot analysis, Western blot analysis and immunohistochemistry.

\section{Embryoculture}

Embryo culture techniques were performed using the methods of New [44]. On day 9 of gestation, conceptuses were excised, floated in petri dishes containing Hanks' balanced salt solution and freed of decidua. Reichert's membrane was opened and intact embryo units (embryos together with their visceral yolk sac, amnion and ectoplacental cone) were explanted into culture media. Sterile culture media consisted of the immediately centrifuged, heat-inactivated serum from normal female rats diluted 3:1 with isotonic saline $(0.85 \% \mathrm{NaCl})$ to obtain a final glucose concentration of $6.6 \mathrm{mmol} / \mathrm{l}$ as control medium. The latter was isosmotically replaced by $5 \% \mathrm{D}-$ glucose in saline to obtain a high glucose medium containing additional 33.3, $66.6 \mathrm{mmol} / 1$ glucose concentrations. Each culture tube containing six embryo units in $6 \mathrm{ml}$ medium was incubated at $37^{\circ} \mathrm{C}$ with rotation in a temperature-controlled incubator. Embryo units were transferred to new culture vessels after $24 \mathrm{~h}$ and resuspended in $6 \mathrm{ml}$ of fresh culture medium for the second 24-h period. The embryo units were removed from the culture vessels at the end of $48 \mathrm{~h}$ on day 11 of development. 

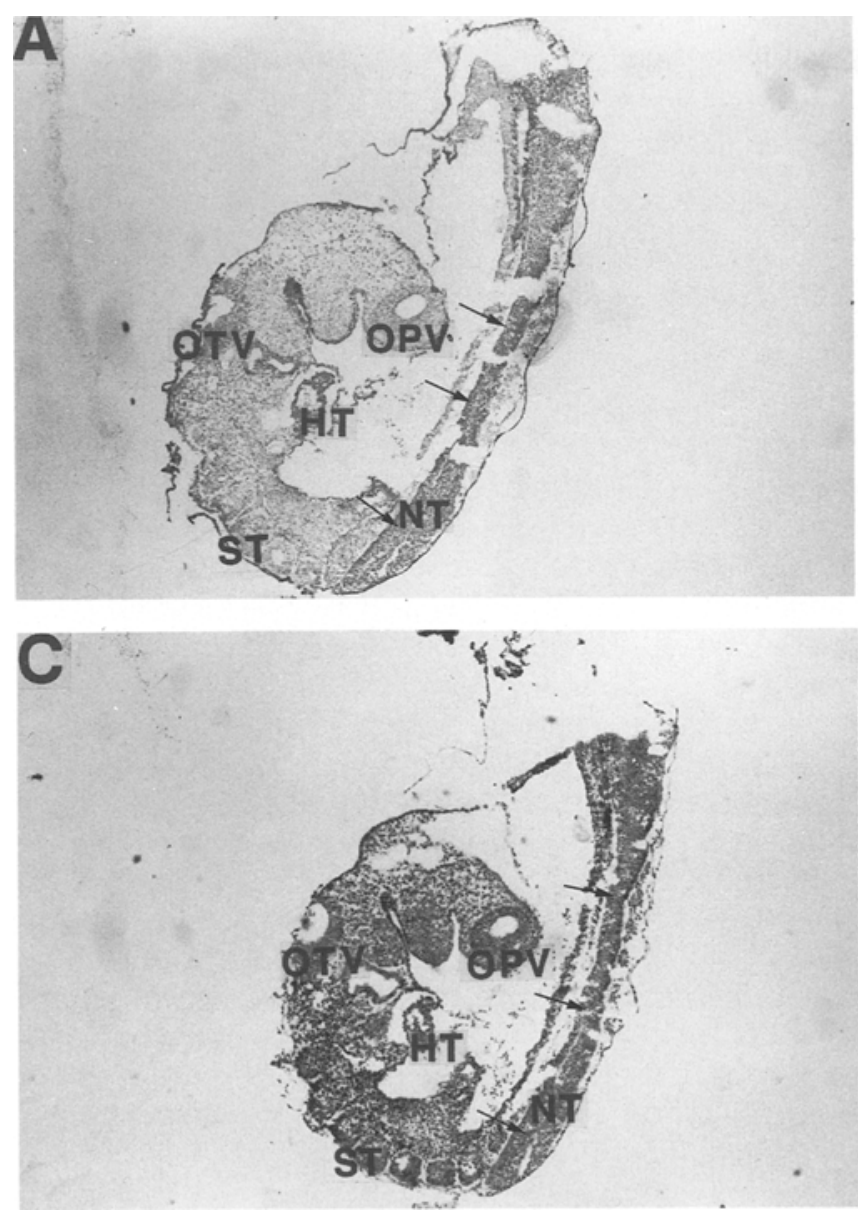

\section{Northern blot analysis}

Embryos were quickly separated from the yolk sac and amnion under a dissecting microscope, immediately frozen and stored in liquid nitrogen to ensure the preservation of RNA. Embryos and yolk sacs were homogenized and total cellular RNA was extracted by the acid guanidinium thiocyanate-phenol-chloroform method [45]. Total RNA $(30 \mu \mathrm{g})$ was denatured, electrophoresed on $1 \%$ formaldehyde agarose gels, blotted, transferred to a nylon membrane (Hybond N; Amersham, Arlington Heights, IL., USA) and then fixed under ultraviolet light. The GLUT-1 probe, a 2.4 kilobase $(\mathrm{kb})$ pair fragment of the HEpG2 cDNA which included the region downstream from the internal Bam HI site [3], GLUT-3 probe, 562 base pair (bp) fragment of mouse GLUT-3 cDNA [7] and GLUT-4 probe, 795 bp fragment of polymerase chain reaction (PCR)-amplified rat muscle cDNA [8], were labelled with $\left[\alpha-{ }^{32} \mathrm{P}\right]$ dCTP (Amersham) by a modified random priming technique and separated from the unincorporated dCTP by gel filtration chromatography. These probes were hybridized to RNA immobilized on the nylon membrane in a solution containing $50 \%$ formamide, $5 \times$ Denhardt's solution, $1 \%$ sodium dodecyl sulphate (SDS) and $5 \times \mathrm{SSPE} \quad\left(1 \times \mathrm{SSPE}=150 \mathrm{mmol} / \mathrm{l} \quad \mathrm{NaCl}, 10 \mathrm{mmol} / 1 \quad \mathrm{NaH}_{2} \mathrm{PO}_{4}\right.$, $1 \mathrm{mmol} / \mathrm{l} \mathrm{EDTA}, \mathrm{pH} 7.4$ ) at $42^{\circ} \mathrm{C}$ for $24 \mathrm{~h}$. The membrane was washed twice in $2 \times \mathrm{SSC}(1 \times \mathrm{SSC}=150 \mathrm{mmol} / \mathrm{l} \mathrm{NaCl}, 15 \mathrm{mmol} / 1$ sodium citrate, $\mathrm{pH} 7.4), 0.1 \% \mathrm{SDS}$ at room temperature and once in $1 \times \mathrm{SSC}, 0.1 \% \mathrm{SDS}$ for $20 \mathrm{~min}$ at $55^{\circ} \mathrm{C}$. The membrane was exposed to the Kodak X OMAT AR film at $-70^{\circ} \mathrm{C}$ for 3 days. After stripping of the glucose transporter probe, the papers were then rehybridized with $\beta$-actin cDNA probe labelled with $\left[\alpha-{ }^{32} \mathrm{P}\right]$ dCTP. The autoradiographic bands obtained by Northern blotting were then quantified by scanning densitometry.

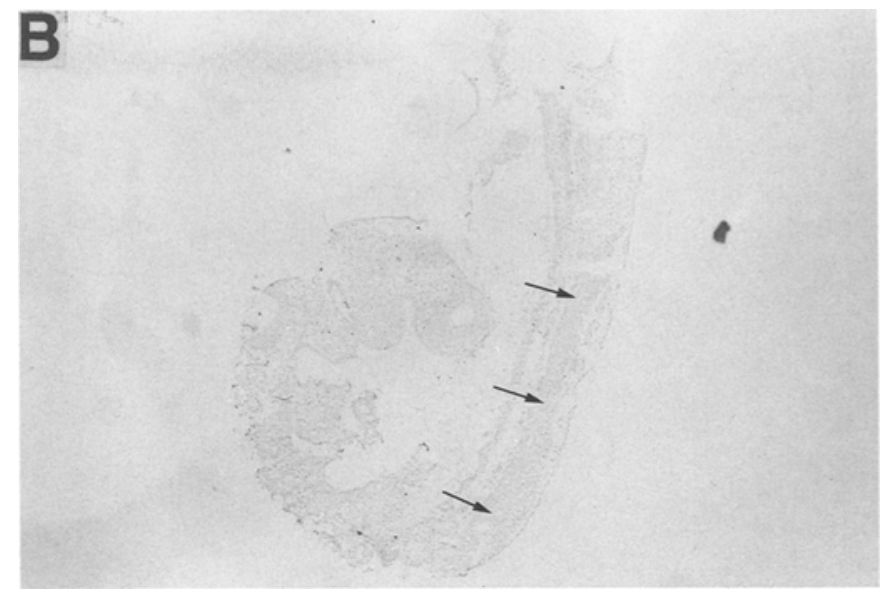

Fig. 4A-C. Immunohistochemical staining of GLUT-1 protein of the embryo on day 10 (original magnification $\times 40$ ). Sagittal section of the embryo on day 10 was treated with rabbit GLUT-1 antiserum (1:100) (A) and normal (non-immune) rabbit serum (1:100) (B). (C) represents a section stained with haematoxylin-eosin. GLUT-1 protein immunoreactivity was principally observed in the neuroepithelium of the neural tube (NT), the heart (HT), the optic vesicle (OPV) and the otic vesicle (OTV) but was not found in the somite (ST). Arrows indicate neural tube

\section{Western blot analysis}

Embryo and yolk sac were separately thawed in a homogenizing buffer consisting of $20 \mathrm{mmol} / 1 \mathrm{HEPES}, 1 \mathrm{mmol} / \mathrm{l}$ EDTA, $250 \mathrm{mmol} / 1 \mathrm{suc}-$ rose, $1 \mathrm{mmol} / \mathrm{l}$ phenylmethylsulphonyl fluoride, $10 \mathrm{mmol} / 1$ iodoacetoamide, and $1 \%$ Triton X-100 with a dounce homogenizer. Homogenates were centrifuged at $12,000 \mathrm{rev} / \mathrm{min}$ at $4^{\circ} \mathrm{C}$ for $10 \mathrm{~min}$, and the protein content determined by the Bio-Rad protein dye assay with bovine plasma gamma globulin as standard. Total protein $(50 \mu \mathrm{g})$ was resolved by SDS-polyacrylamide gel electrophoresis (PAGE) using a $10 \%$ gel, electrically transferred to nitrocellulose paper. The blots were blocked with mild shaking in phosphate-buffered saline (PBS) with $5 \%$ powdered milk at $4^{\circ} \mathrm{C}$ overnight. They were then incubated with a 1:2500 dilution of a GLUT-1 antiserum raised against the $\mathrm{COOH}$-terminal of rat brain glucose transporter [1] in PBS containing $1 \%$ powdered milk for $60 \mathrm{~min}$ at $37^{\circ} \mathrm{C}$ and incubated with ${ }^{125} \mathrm{I}$-labelled protein A (Amersham). The filters were washed, air dried, and exposed to Kodak X OMAT AR film at $-70^{\circ} \mathrm{C}$ for 3 days. Bands on the autoradiograms were quantified by scanning densitometry.

\section{Immunohistochemistry}

After the quick separation of embryo from membrane fraction under the dissecting microscope, the embryo was immersed and fixed in $4 \%$ paraformaldehyde, and immersed in $20 \%$ sucrose and embedded in O.C.T. compound (Tissue Teck, Los Angeles, CA, USA). The frozen sections were cut at $46 \mu \mathrm{m}$ on a Bright cryostat. After pretreatment with $0.3 \% \mathrm{H}_{2} \mathrm{O}_{2}$ and normal rabbit sera, 1 -h incubation at room temperature with GLUT-1 antiserum (1:100 dilu- 

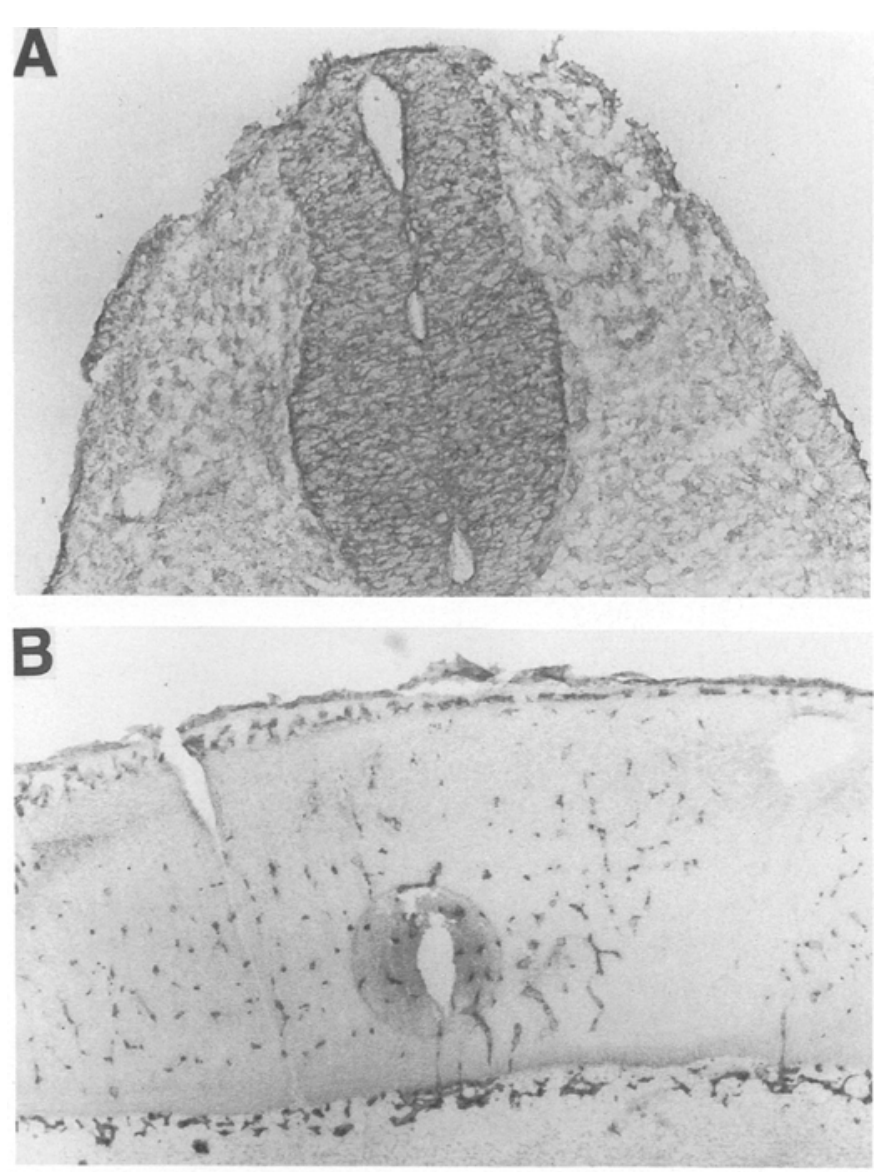

Fig.5A-C. Immunohistochemical staining of GLUT-1 protein of neural tube of the embryo on day 11 (A) and day 13 (B) (original magnification $A ; \times 100, B ; \times 50)$. Transverse section of the embryo on day 11 and day 13 were treated with rabbit GLUT-1 antiserum. (C) represents a transverse section of embryo on day 13 in treatment with normal (non-immune) rabbit serum (1:100) (original magnification $\times 50$ ). GLUT-1 protein immunoreactivity was observed in the neuroepithelium on day 11 and the microvessels on day 13

tion in PBS) was performed. The primary antibody incubation was then followed by the incubation with peroxidase-labelled protein $A$ (Sigma, St. Louis, MO., USA) (1: ll dilution in PBS) secondary antibody for $45 \mathrm{~min}$ and with 3,3'-1-diaminobenzidine- $0.03 \% \mathrm{H}_{2} \mathrm{O}_{2}$ for 5 min. For control, normal rabbit serum (1:100) and PBS buffer alone were used with omission of the GLUT-1 antiserum.
Statistical analysis

All data are presented as mean \pm SEM. Group comparisons were performed using Student's $t$-test for unpaired groups. Intergroup differences for comparison of morphologic lesions in embryos were assessed by chi-square analysis.

\section{Results}

Northern blot analysis revealed the presence of both GLUT- 1 and GLUT- 3 mRNA in the embryo and yolk sac during the period of organogenesis (Fig.1, Fig.2). GLUT-1 mRNA in the embryo and yolk sac hybridized to the GLUT-1 cDNA probe was about $2.8 \mathrm{~kb}$ in size, similar to that reported previously [1,2] (Fig. 1). GLUT-1 mRNA expression was most abundant in the embryo on day 10 of gestation and decreased as the gestation progressed, while persistently abundant expression of GLUT-1 mRNA was observed in the yolk sac during day 10-13 of gestation (Fig. 1). Mouse GLUT-3 cDNA was probe-hybridized to a single transcript of about $4 \mathrm{~kb}$ in the embryo and yolk sac (Fig.2), indicating no discernible cross-hybridization between GLUT-1 and GLUT-3 mRNA. GLUT-3 mRNA was expressed in the embryo and yolk sac during the early stage of organogenesis (Fig.2).

The GLUT-4 cDNA probe did not hybridize to RNA from the embryo and yolk sac (data not shown). The autoradiogram of the Western blot of GLUT-1 protein is shown in Figure 3. The size of GLUT-1 protein bound to GLUT-1 antibody was approximately $45 \mathrm{kDa}$. Similar to the level of GLUT-1 mRNA expression, GLUT-1 protein level was the highest in the embryo on day 10 , followed by gradual decline as the embryo developed. In the yolk sac high levels of GLUT-1 protein were observed during day 11-13 of gestation.

Immunohistochemical staining of GLUT-1 protein in the embryo which by Western blot showed their highest level on day 10 was found principally in the neuroepithelium and also in the heart (Fig. 4A). However, immunoreactivity of GLUT-1 protein in the embryo, which by Western blot showed lower expression on day 13 , was found in the microvessels surrounding neural tube, but much decreased in the neuroepithelial cells (Fig.5). Further experiments were performed to examine whether the glucose transporter genes (GLUT-1 and GLUT-3 mRNA) and protein (GLUT-1) in the embryo and yolk sac, all of which were predominantly expressed during day $9-10$, could be regulated in culture with high glucose medium. The expression of GLUT-1 and GLUT-3 mRNA in the embryo and yolk sac was not down-regulated in culture with high glucose media containing an additional $33.3 \mathrm{mmol} / \mathrm{l}$ and $66.6 \mathrm{mmol} / \mathrm{l}$ glucose for $24 \mathrm{~h}$ (Fig. 6, Fig. 7) and $48 \mathrm{~h}$ (data not shown) compared to control. The levels of GLUT-1 protein as well as glucose transporter genes were not suppressed by culturing in high glucose media for $24 \mathrm{~h}$ (Fig. 8). However, GLUT-1 protein significantly decreased in the embryo and yolk sac, when cultured in media containing an additional $33.3 \mathrm{mmol} / \mathrm{l}$ and $66.6 \mathrm{mmol} / \mathrm{glu}$ cose for $48 \mathrm{~h}$ (Fig. 9). Immunohistochemical staining of 


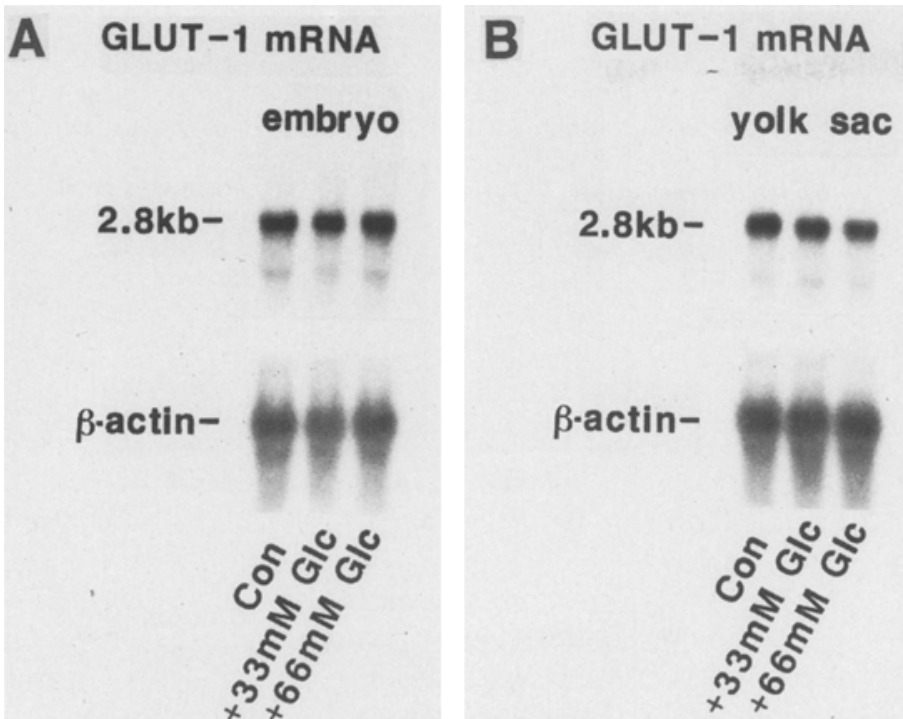

Fig.6A-D. Representative Northern blot $(\mathbf{A}, \mathbf{B})$ and quantitation $(\mathbf{C}, \mathbf{D})$ of GLUT-1 mRNA from the embryo and yolk sac cultured in control or high glucose medium for $24 \mathrm{~h}$. Rat conceptuses on day 9 were cultured for $24 \mathrm{~h}$ in control (Con) and medium supplemented with $33.3 \mathrm{mmol} / \mathrm{l}$ glucose ( $+33 \mathrm{mM} \mathrm{Glc})$ and $66.6 \mathrm{mmo} / \mathrm{l}$ glucose $(+66 \mathrm{mM} \mathrm{Glc})$. Northern blot analysis was performed in the separated embryo and yolk sac as described in Figure 1. The optical density values were expressed in arbitrary units of absorbance relative to the value showing the maximal level of GLUT-1 mRNA for each tissue. Each bar is mean \pm SEM for three independent determinations
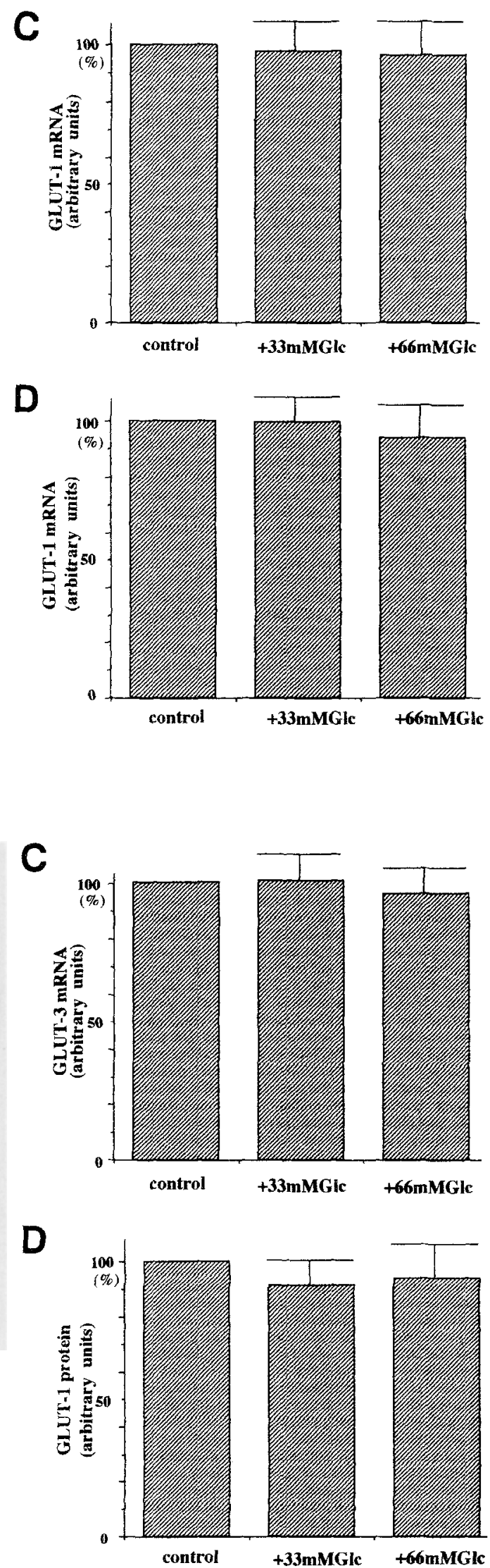

Fig.7A-D. Representative Northern blot $(\mathbf{A}, \mathbf{B})$ and quantitation $(\mathbf{C}, \mathbf{D})$ of GLUT-3 mRNA from the embryo and yolk sac cultured in control and high glucose medium for $24 \mathrm{~h}$. Rat conceptuses were cultured for $24 \mathrm{~h}$ in control (Con) and medium supplemented with $33.3 \mathrm{mmol} / \mathrm{l}$ glucose $(+33 \mathrm{mM} \mathrm{Glc})$ and $66.6 \mathrm{mmol} / \mathrm{glucose}(+66 \mathrm{mM}$ Glc). Northern blot analysis was performed in the separated embryo and yolk sac as described in Figure 1. The optical density values were expressed in arbitrary units of absorbance relative to the value of the culture condition showing the maximal level of GLUT-3 mRNA. Each bar is mean \pm SEM for three independent determinations

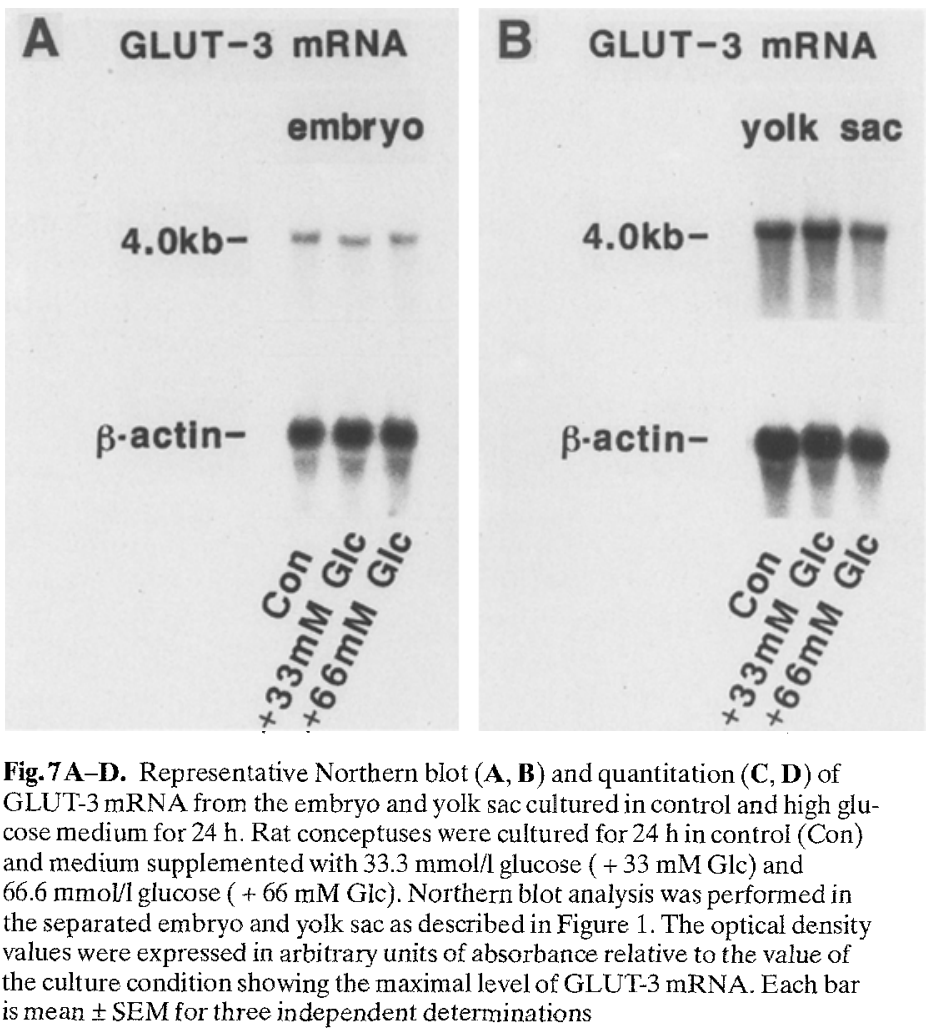




\section{A}

GLUT-1 protein

embryo

45KDa-

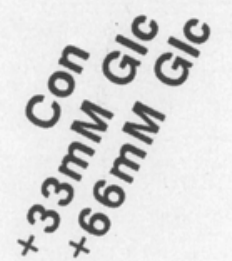

B

GLUT-1 protein

yolk sac
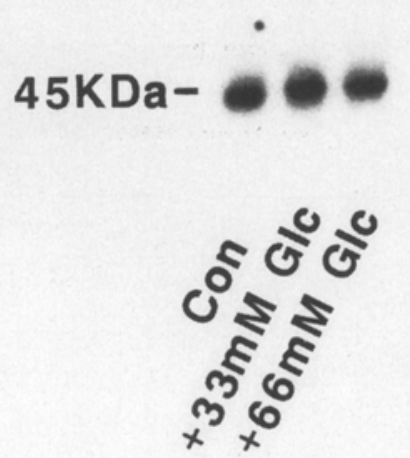

C

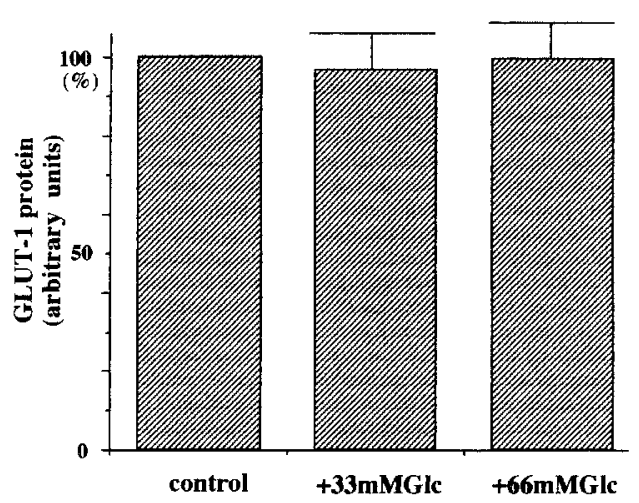

$\mathbf{D}$

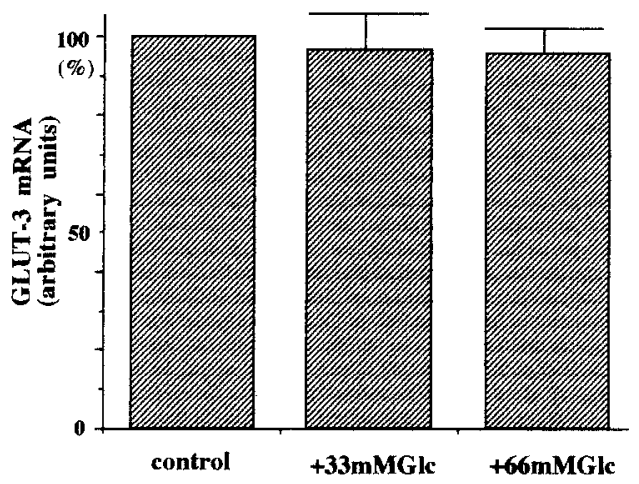

Fig.8 A-D. Representative Western blot (A, B) and quantitation $(\mathbf{C}, \mathbf{D})$ of GLUT-1 protein from the embryo and yolk sac cultured in control and high glucose medium for $24 \mathrm{~h}$. Rat conceptuses were cultured for $24 \mathrm{~h}$ in control (Con) and medium sup-

plemented with $33.3 \mathrm{mmol} / \mathrm{lglucose}(+33 \mathrm{mM} \mathrm{Glc})$ and $66.6 \mathrm{mmol} / \mathrm{lglucose}(+66 \mathrm{mM}$ Glc). Western blot analysis was performed in the separated embryo and yolk sac as described in Figure 3. The optical density values were expressed in arbitrary units of absorbance relative to the value showing the maximal level of GLUT-1 protein. Each bar is mean \pm SEM. Rat conceptuses on day 9 were cultured in control (Con) and high glucose medium containing additional $33.3 \mathrm{mmol} / \mathrm{h}$ glucose $(+33 \mathrm{mM} \mathrm{Glc})$ and $66.6 \mathrm{mmol} / \mathrm{l}$ glucose ( + $66 \mathrm{mM} \mathrm{Glc)}$ for $24 \mathrm{~h}$
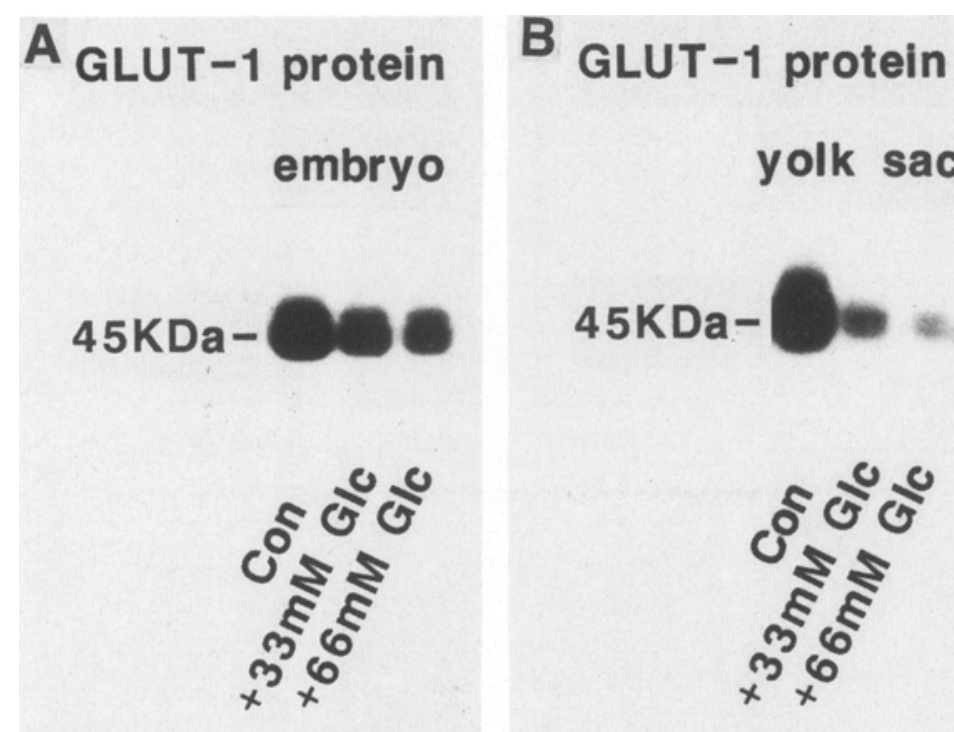

yolk sac
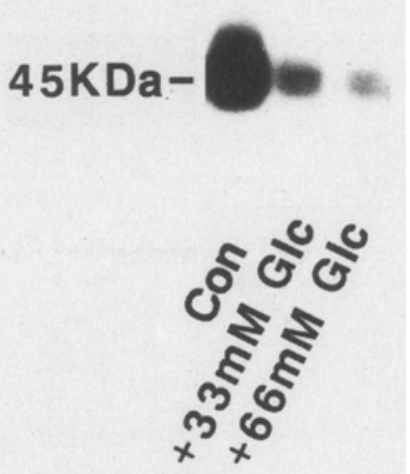

Fig.9A-D. Representative Western blot (A, B) and quantitation (C, D) of GLUT-1 protein from the embryo and yolk sac cultured in control and high glucose medium for $48 \mathrm{~h}$. Rat conceptuses were cultured for $48 \mathrm{~h}$ in control (Con) and medium supplemented with $33.3 \mathrm{mmol} / \mathrm{l}$ glucose (+ $33 \mathrm{mM} \mathrm{Glc})$ and $66.6 \mathrm{mmol} / \mathrm{l}$ glucose $(+66 \mathrm{mM}$ Glc). Western blot analysis was performed in the separated embryo and yolk sac as described in Figure 3. The optical density values were expressed in arbitrary units of absorbance relative to the value showing the maximal level of GLUT-1 protein. Each bar is mean \pm SEM. $* p<0.01$ vs control
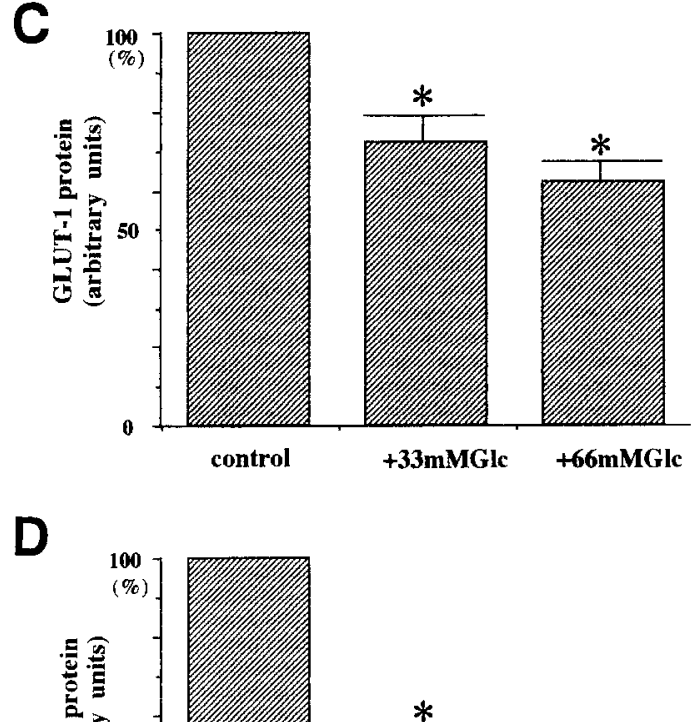

D

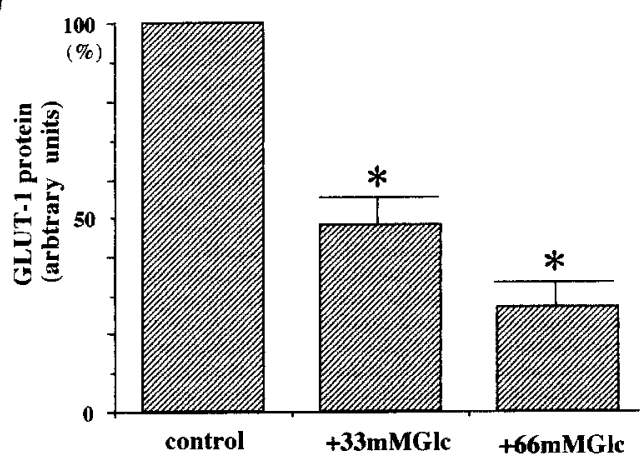



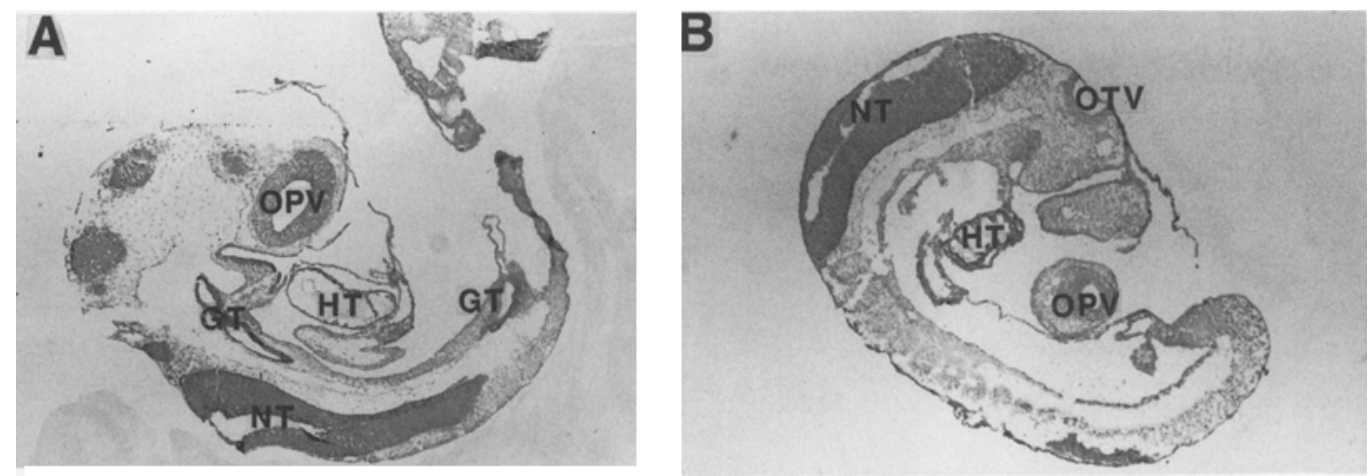

Fig. 10 A, B. Sagittal sections of immunohistochemical staining of GLUT-1 protein in the embryo (on day 10) cultured in control (A) and high glucose medium (B). Rat conceptuses on day 9 were cultured in control medium and medium supplemented with $33.3 \mathrm{mmol} / \mathrm{l}$ glucose (B) for $24 \mathrm{~h}$. Immunohistochemistry was performed as described in Figure 4. GLUT-1 protein immunoreactivity was more prominent in the neural tube (NT) and also in the optic vesicle (OPV), the otic vesicle (OTV), the gut (GT) and the heart (HT)

GLUT-1 protein in embryos cultured in control and high glucose medium for $24 \mathrm{~h}$ is shown in Figure 10. GLUT-1 immunoreactivity in embryos cultured in high glucose medium was prominent and not down-regulated, when compared to control. Also, the tissue distribution of GLUT-1 protein was not changed during the high glucose culture (Fig. 10).

Control embryos explanted at the early head fold stage (day 9 of gestation) which developed normally during the 48-h culture period were indistinguishable from those observed in vivo. These embryos showed a clearly delineated brain, complete closure of the neural tube, well-formed otic and optic vesicles and normal heart development of an S-shaped tubular heart and complete axial rotation with a ventrally concave C-shaped curvature. In contrast, those embryos cultured in high glucose for $48 \mathrm{~h}$ exhibited an increased frequency of the neural defects associated with growth retardation (Table 1).

\section{Discussion}

In the present study, we demonstrated the predominant expression of high affinity glucose transporters (GLUT-1 and GLUT-3) mRNA in embryo and yolk sac during the early period of organogenesis. The level of GLUT-1 protein in the embryo increased in parallel with the expression of GLUT-1 mRNA, showing the highest level on day 10. Immunohistochemical staining of GLUT-1 protein showed high expression in the neuroepithelium, which did not decrease with 24-h high glucose culture (day 9-10) during the critical period of neural tube formation and was only down-regulated (day 9-11) by prolonged ( $48 \mathrm{~h}$ ) high glucose exposure. The embryos cultured in high glucose showed an increased frequency of neural tube defects.
The conceptus during this period consisted of the embryo and extraembryonic membrane such as allantois, amnion and yolk sac. In the circulatory system, the yolk sac circulation begins to be established on day 10 and is fully developed by day 11 . Since the chorioallantoic circulation is not formed until day 11 , the embryo at this stage takes the nutrients (such as glucose and amino acids) or oxygen via direct diffusion from the yolk sac and then via the yolk sac circulation. The major energy production system of conceptus during early organogenesis is characterized by anaerobic glycolysis; a very high rate of glucose utilization and conversion to lactic acid has been demonstrated $[11,12]$. Our finding that the high affinity glucose transporter genes (GLUT 1 and GLUT 3) and protein (GLUT 1) were expressed predominantly in the embryo and yolk sac during early organogenesis is consistent with the high requirement of glucose under glycolytic dependence. In a short-term incubation study of the separated embryo and extraembryonic membrane (including yolk sac), the finding that the rate of glycolysis in the yolk sac is much higher than that in the separate embryo (S, Akazawa and B.E.Metzger, unpublished data) was also consistent with higher expression of the high affinity glucose transporter genes and protein in the yolk sac than embryo.

During days 9 to 11 of gestation the major part of neural tube formation of the rat embryo occurs; the elevation and subsequent apposition of the neural fold and closure of the neural tube are completed by closing the posterior neuropore on day 11.3. High expression of GLUT-1 mRNA and GLUT-1 protein in the embryo was observed during day 9-11 during the major part of neural tube formation. Strong immunohistochemical staining of GLUT1 protein of the embryo on day 10 was observed in neuroepithelium surrounding the neural tube. The level of GLUT-1 mRNA and protein decreased as gestational age progressed, especially after day 12 , when complete closure of the neural tube takes place. Immunoreactivity of GLUT-1 protein of embryo decreased considerably in the neuroepithelium after day 12 and was then found in the microvessels surrounding the neural tube. GLUT-1 and GLUT-3 mRNA have been reported to be expressed in most adult tissues and to be abundant in the brain [46-49], although the expression of the GLUT-3 gene is restricted to the brain of rat and mouse. GLUT 1 and GLUT 3 are expressed differently in the brain; GLUT 1 , 
Table 1. Effects on growth and development of embryo after exposure to high glucose serum

\begin{tabular}{|c|c|c|c|c|c|}
\hline $\begin{array}{l}\text { Normal culture } \\
\text { medium } \\
\text { supplemented with }\end{array}$ & $n$ & $\begin{array}{l}\text { Crown rump } \\
(\mathrm{mm})\end{array}$ & $\begin{array}{l}\text { Somite } \\
\text { (n) }\end{array}$ & $\begin{array}{l}\text { Major } \\
\text { lesions } \\
(\%)\end{array}$ & $\begin{array}{l}\text { Minor } \\
\text { lesions } \\
(\%)\end{array}$ \\
\hline 0 & 49 & $3.35 \pm 0.04$ & $28.3 \pm 0.1$ & 0 & 6.1 \\
\hline $33.3 \mathrm{mmol} / 1 \mathrm{D}$-glucose & 43 & $3.16 \pm 0.07^{\mathrm{a}}$ & $26.3 \pm 0.7^{b}$ & 4.7 & $30.2^{\mathrm{b}}$ \\
\hline $66.6 \mathrm{mmol} / \mathrm{l} \mathrm{D}-\mathrm{glucose}$ & 35 & $2.85 \pm 0.09^{b}$ & $25.7 \pm 0.6^{\mathrm{b}}$ & $22.8^{\mathrm{b}}$ & $45.7^{\mathrm{b}}$ \\
\hline
\end{tabular}

Number of embryos examined indicated by $n$. Major lesions are neural lesions consisting of defects of neural tube closure, adhesion of posterior and anterior neural tube, and brain malformations. Minor lesions are defects in axial rotation or lesions involving the optic and otic vesicles, heart, pericardial cavity or skeletal system.

${ }^{\mathrm{a}} p<0.05,{ }^{\mathrm{b}} p<0.01$ vs embryos cultured in control media

in the endothelial cells of the blood-brain barrier $[50,51]$ and GLUT 3, in the brain parenchymal cells [7]. GLUT-1 protein immunoreactivity has been reported to be distributed in the brain vascular endothelial cells or the fetus and neonate in rat and rabbit [46-48]. Altogether GLUT1 protein is initially distributed in the neuroepithelium during the period of neural tube formation (day 9-11) and then in the microvessel after the closure of neural tube (day 12). Smith and Gridley [52] recently reported that expression of GLUT-1 and GLUT-3 mRNA in early postimplantation mouse embryo by in situ hybridization. They reported that both glucose transporters were expressed more strongly in extraembryonic tissue (including yolk sac and amnion) than in the embryo. Expression of GLUT-1 mRNA was widespread in the embryo (spinal cord, eye), while GLUT-3 mRNA expression was confined to (non-neural) surface ectoderm of embryo [52]; these are similar to our results. In the next experiment, we investigated the regulation of the high affinity glucose transporter genes (GLUT 1 and GLUT 3 ) and the protein (GLUT 1) in the embryo and yolk sac in high glucose culture. We, and others $[22,24,26]$ have reported that the addition of glucose to culture media caused an excess accumulation of intracellular glucose which resulted in increased sorbitol accumulation and reduced myo-inositol content in the embryos in a dose-dependent fashion. The decrease of myo-inositol content may be attributable to the competitive inhibition by glucose of myo-inositol transport into the developing conceptus [26]. Myo-inositol supplementation to the culture media resulted in a significantly decreased incidence of malformation with complete restoration of myo-inositol contents in the embryos $[24,25]$, while aldose reductase inhibitor did not modify the incidence of malformations [22, 24]. Hyperglycaemia-induced teratogenesis has been suggested to be mediated by myo-inositol depletion in the embryos at a critical stage of organogenesis, which may be caused by competition with ambient glucose for uptake. Eriksson et al. [27] reported that the addition of free oxygen radical scavenging enzymes to high glucose culture media could protect hyperglycaemia-induced embryonic malformations, indicating that hyperglycaemia-induced embryopathy might be caused by generation of free oxygen radicals. In any case, an increased flux of glucose into the cell by hyperglycaemia may cause the excess formation of free oxygen radicals and myo-inositol depletion by competing with ambient glucose, leading to abnormal embryonic development.
It has been demonstrated that the ambient glucose concentration regulates the glucose transport activity in a variety of cell types. Glucose deprivation resulted in a specific elevation of glucose transport activity [30-34], which was associated with an increase in the number of glucose transporters. On a molecular basis, it was reported that the increase of glucose transport activity is associated with increased levels of GLUT-1 mRNA or protein in rat brain glial cells [33], primary cultured adipocytes [35], 3T3 adipocyte [36] and L6 muscle cells [34, 37]. Contrary to hypoglycaemia, hyperglycaemia has been reported to drecease glucose transport activity in many cell types [35, 39-43], indicating down-regulation of the glucose transport system. The decreased activity is associated with a decreased number of glucose transporters or reduced levels of the glucose transporter gene and/or protein in the primary cultured adipocytes [35], microvessels of blood brain barrier [39], rat adipocytes [41], 3T3-L1 fibroblasts [42] and hamster-derived pancreatic beta-cell line (HIT) [43].

In our experiments, the high expression of GLUT-1 protein was not down-regulated during the 24-h high glucose culture (day 9-10) but down-regulated only during the prolonged (48 h) exposure to high glucose (day 9-11). The levels of GLUT-1 and GLUT-3 mRNA were not affected by the 24-h high glucose culture. The first $24 \mathrm{~h}$ of culture (day 9-10) in high glucose medium have been shown to be the critical period during which embryonic malformations such as neural tube defects can be induced [17-20]. The lack of down-regulation and continuous, high expression of the high affinity glucose transporters during this critical period may permit an increased flux of glucose into the differentiating neuroepithelial cells, which may induce the generation of free oxygen radicals or myo-inositol depletion.

In summary, the abundant expression of high affinity glucose transporters in the rat embryo during the major period of neural tube formation was demonstrated. This increased expression of glucose transporters was not down-regulated during the critical developing period in the presence of high glucose, which may permit increased glucose flux into the neuroepithelial cells. This process may be one of those involved in neural tube defects induced by hyperglycaemia.

Acknowledgements. We thank Dr.S. Nagamatsu for providing us with mouse GLUT-3 cDNA. We acknowledge the expert technical assistance of Ms A. Nakashima and Ms M. Ikenaga. 


\section{References}

1. Birnbaum MJ, Haspel HC, Rosen OM (1986) Cloning and characterization of a cDNA encoding the rat brain glucose-transporter protein. Proc Natl Acad Sci USA 83: 5784-5788

2. Fukumoto H, Seino S, Imura H, Seino Y, Bell GI (1988) Characterization and expression of human HepG2/erythrocyte glucose transporter gene. Diabetes 37: 657-661

3. Flier JS, Mueckler M, McCall AL, Lodish HF (1987) Distribution of glucose transporter messenger RNA transcripts in tissues of rat and man. J Clin Invest 79:657-661

4. Fukumoto H, Seino S, Imura H et al. (1988) Sequence, tissue distribution, and chromosomal localization of mRNA encoding a human glucose transporter-like protein. Proc Natl Acad Sci USA 85: 5434-5438

5. Permutt MA, Koranyi L, Keller K, Lacy PE, Scharp DW, Mueckler M (1989) Cloning and functional expression of human pancreatic islet glucose-transporter cDNA. Proc Natl Acad Sci USA 86: 8688-8692

6. Kayano T, Fukumoto H, Eddy RL et al. (1988) Evidence for a family of human glucose transporter-like proteins. J Biol Chem 263: $15245-15248$

7. Nagamatsu S, Kornhauser JM, Burant CF, Seino S, Mayo KE, Bell GI (1992) Glucose transporter expression in brain. cDNA sequence of mouse GLUT 3, the brain facilitative glucose transporter isoform, and identification of sites of expression by in situ hybridization. J Biol Chem 267: 467-472

8. James DE, Strube M, Mueckler M (1989) Molecular cloning and characterization of an insulin-regulatable glucose transporter. Nature 338: 83-87

9. Kayano T, Burant CF, Fukumoto H et al. (1990) Human facilitative glucose transporters. Isolation, functional characterization, and gene localization of cDNAs encoding an isoform (GLUT5) expressed in small intestine, kidney, muscle, and adipose tissue and an unusual glucose transporter pseudo-gene like sequence (GLUT6). J Biol Chem 265: 13276-13282

10. Shepard TH, Tanimura T, Robkin MA (1970) Energy metabolism in ealy mammalian embryos. Symp Soc Dev Biol 29: 42-58

11. Tanimura T, Shepard TH (1970) Glucose metabolism by rat embryos in vitro. Proc Soc Exp Biol Med 135: 51-54

12. Freinkel N, Lewis NJ, Akazawa S, Roth SI, Gorman L (1984) The honeybee syndrome-implications of the teratogenicity ofmannose in rat-embryo culture. N Engl J Med 310: 223-230

13. Buchanan TA, Schemmer JK, Freinkel N (1986) Embryotoxic effects of brief maternal insulin-hypoglycemia during organogenesis in the rat. J Clin Invest 78: 643-649

14. Akazawa S, Akazawa M, Hashimoto M et al. (1987) Effects of hypoglycaemia on early embryogenesis in rat embryo organ culture. Diabetologia 30:791-796

15. Ellington SKL (1987) Development of rat embryos cultured in glucose-deficient media. Diabetes 36: 1372-1378

16. Akazawa M, Akazawa S, Hashimoto M et al. (1989) Effects of brief exposure to insulin-induced hypoglycemic serum during organogenesis in rat embryo culture. Diabetes 38: 15731578

17. Cockroft DL, Coppola PT (1977) Teratogenic effects of excess glucose on head-fold rat embryos in culture. Teratology 16: 141146

18. Sadler TW (1980) Effects of maternal diabetes on early embryogenesis: I. The teratogenic potential of diabetic serum. Teratology 21: 339-347

19. Sadler TW (1980) Effects of maternal diabetes on early embryogenesis: II. Hyperglycemia-induced exencephaly. Terato$\operatorname{logy} 21: 349-356$

20. Garnham EA, Beck F, Clarke CA, Stanisstreet M (1983) Effects of glucose on rat embryos in culture. Diabetologia 25:291-295

21. Freinkel N, Cockroft DL, Lewis NJ et al. (1986) The $1986 \mathrm{McCol}-$ lum award lecture. Fuel-mediated teratogenesis during early organogenesis: the effects of increased concentrations of glucose, ketones, or somatomedin inhibitor during rat embryo culture. Am J Clin Nutr 44: 986-995
22. Hod M, Star S, Passonneau JV, Unterman TG, Freinkel N (1986) Effect of hyperglycemia on sorbitol and myo-inositol content of cultured rat conceptus: failure of aldose reductase inhibitors to modify myo-inositol depletion and dysmorphogenesis. Biochem Biophys Res Comm 140: 974-980

23. Sussman I, Matschinsky FM (1988) Diabetes affects sorbitol and myo-inositol levels of neuroectodermal tissue during embryogenesis in rat. Diabetes 37: 974-981

24. Hashimoto M, Akazawa S, Akazawa M et al. (1990) Effects of hyperglycaemia on sorbitol and myo-inositol contents of cultured embryos: treatment with aldose reductase inhibitor and myo-inositol supplementation. Diabetologia 33: 597602

25. Akashi M, Akazawa S, Akazawa M et al. (1991) Effects of insulin and myo-inositol on embryo growth and development during early organogenesis in streptozocin-induced diabetic rats. Diabetes 40: 1574-1579

26. Weigensberg MJ, Garcia-Palmer FJ, Freinkel N (1990) Uptake of myo-inositol by early-somite rat conceptus: transport kinetics and effects of hyperglycemia. Diabetes 39: 575-582

27. Eriksson UJ, Borg LAH (1991) Protection by free oxygen radical scavenging enzymes against glucose-induced embryonic malformations in vitro. Diabetologia 34:325-331

28. Flier JS, Mueckler MM, Usher P, Lodish HF (1987) Elevated levels of glucose transport and transporter messenger RNA are induced by ras and sre oncogenes. Science 235: 1492-1495

29. Hiraki Y, Rosen OM, Birnbaum MJ (1988) Growth factors rapidly induce expression of the glucose transporter gene. J Biol Chem 263: 13655-13662

30. Pessin JE, Tillotson LG, Yamada K et al. (1982) Identification of the stereospecific hexose transporter from starved and fed chicken embryo fibroblasts. Proc Nall Acad Sci USA 79: 22862290

31. Yamada K, Tillotson LG, Isselbacher KJ (1983) Regulation of hexose carriers in chicken embryo fibroblasts: effect of glucose starvation and role of protein synthesis. J Biol Chem 258: 97869792

32. Haspel HC, Wilk EW, Birnbaum MJ, Cushman SW, Rosen OM (1986) Glucose deprivation and hexose transporter polypeptides of murine fibroblasts. J Biol Chem 261: 6778-6789

33. Walker PS, Donovan JA, Van Ness BG, Fellows RE, Pessin JE (1988) Glucose-dependent regulation of glucose transport activity, protein, and mRNA in primary cultures of rat brain glial cells. J Biol Chem 263: 15594-15601

34. Walker PS, Ramlal T, Donovan JA et al. (1989) Insulin and glucose-dependent regulation of the glucose transport system in the rat L6 skeletal muscle cell line. J Biol Chem 264: 65876595

35. Garvey WT, Olefsky JM, Matthaei S, Marshall S (1987) Glucose and insulin co-regulate the glucose transport system in primary cultured adipocytes. A new mechanism of insulin resistance. J Biol Chem 262: 189-197

36. Van Putten JPM, Krans HMJ (1985) Glucose as a regulator of insulin-sensitive hexose uptake in 3T3 adipocytes. J Biol Chem 260: 7996-8001

37. Walker PS, Ramlal T, Sarabia V et al. (1990) Glucose transport activity in L6 muscle cells is regulated by the coordinate control of subcellular glucose transporter distribution, biosynthesis, and mRNA transcription. J Biol Chem 265: 1516-1523

38. McCall AL, Gould JB, Ruderman NB (1984) Diabetes-induced alterations of glucose metabolism in rat cerebral microvessels. Am J Physiol 247: E462-E467

39. Matthaei S, Horuk R, Olefsky JM (1986) Blood-brain glucose transfer in diabetes mellitus. Decreased number of glucose transporters at blood-brain barrier. Diabetes 35: 1181-1184

40. Gjedde A, Crone C (1981) Blood-brain glucose transfer: repression in chronic hyperglycemia. Science 214: $456-457$

41. Karnieli E, Hissin PJ, Simpson IA, Salans LB, Cushman SW (1981) A possible mechanism of insulin resistance in the rat adipose cell in streptozotocin-induced diabetes mellitus. J Clin Invest $68: 811-814$ 
42. Whitesell RR, Regen DM, Pelletier D, Abumrad NA (1990) Evidence that downregulation of hexose transport limits intracellular glucose in 3T3-L1 fibroblasts. Diabetes 39: 12281234

43. Purrello F, Buscema M, Vetri M et al. (1991) Glucose regulates both glucose transport and the glucose transporter gene expression in a hamster-derived pancreatic Beta-cell line (HIT). Diabetologia 34: 366-369

44. New DAT (1978) Whole-embryo culture and the study of mammalian embryos during organogenesis. Biol Rev 53: 81-122

45. Chomczynski P, Sacchi N (1987) Single-step method of RNA isolation by acid guanidinium thiocyanate-phenol-chloroform extraction. Anal Biochem 162: 156-159

46. Sivitz W, DeSautel S, Walker PS, Pessin JE (1989) Regulation of the glucose transporter in developing rat brain. Endocrinology 124: $1875-1880$

47. Sadiq F, Holtzclaw L, Chundu K, Muzzafar A, Devaskar S (1990) The ontogeny of the rabbit brain glucose transporter. Endocrinology 126: $2417-2424$

48. Devaskar S, Zahm DS, Holtzclaw L, Chundu K, Wadzinski BE (1991) Developmental regulation of the distribution of rat brain insulin-insensitive (Glut 1) glucose transporter. Endocrinology 129: $1530-1540$
49. Yano H, Seino Y, Inagaki $N$ et al. (1991) Tissue distribution and species difference of the brain type glucose transporter (GLUT 3). Biochem Biophys Res Comm 174: 470-477

50. Harik SI, Kalaria RN, Andersson L, Lundahl P, Perry G (1990) Immunocytochemical localization of the erythroid glucose transporter: abundance in tissues with barrier functions. J Neurosci 10: 3862-3872

51. Pardridge WM, Boado RJ, Farrell CR (1990) Brain-type glucose transporter (GLUT-1) is selectively localized to the blood-brain barrier. J Biol Chem 265: 18035-18040

52. Smith DE, Gridley T (1992) Differential screening of a PCRgenerated mouse embryo cDNA library; glucose transporters are differentially expressed in early postimplantation mouse embryos. Development 116: 555-561

Received: 11 January 1993

and in revised form: 12 March 1993

Dr. S. Nagataki

The First Department of Internal Medicine

Nagasaki University School of Medicine Nagasaki 852

Japan 